\title{
Beef acceptance index proposition
}

\author{
Proposição de um índice de aceitação de carne bovina
}

\author{
Thelma Lucchese-Cheung ${ }^{1}$ (D), Eduardo Eugênio Spers² (i), Matheus Wemersom Gomes Pereira ${ }^{1}$ (i), \\ Priscila Caroline Souza Paiva Dias ${ }^{3}$ [D \\ ${ }^{1}$ Universidade Federal de Mato Grosso do Sul (UFMS), Campo Grande (SP), Brasil. E-mail: thelma.lucchese@gmail.com; \\ matheuswgp@yahoo.com.br \\ ${ }^{2}$ Escola Superior de Agricultura Luiz de Queiroz (ESALQ), Universidade de São Paulo (USP), Piracicaba (SP), Brasil. E- \\ mail:edespers@usp.br \\ ${ }^{3}$ Programa De Pós Graduação em Administração (PPGAD), Universidade Federal de Mato Grosso do Sul (UFMS), Campo \\ Grande (MS), Brasil. E-mail: pryhpaiva@hotmail.com
}

How to cite: Lucchese-Cheung, T., Spers, E. E., Pereira, M. W. G. \& Dias, P. C. S. P. (2021). Beef acceptance index proposition. Revista de Economia e Sociologia Rural, 59(2), e223297. https://doi.org/10.1590/1806-9479.2021.223297

Summary: Beliefs, social rules, and food taboos influence the emotions we feel about food, determining our attitudes and consumption behaviors. The more a product represents values considered important to individuals, the greater the chance of being chosen for consumption. This article aimed to investigate levels of zoophagy and sarcophagy to propose an index to understand consumers' attitudes towards beef. Three hundred and eighty-five people answered a structured questionnaire that allowed them to assess personality traits and attitudes that can explain beef consumption, as well as its rejection. Factor analysis was the analytical model chosen to construct the attitude determination index. For the construction of the General Degradation Index (GDI), an attitude determination index associated with the degree of zoophagy was built first. The results indicate that extroversion, individualism, festivity, and immediacy were the traits that best characterized positive attitudes towards beef. On the other hand, negative attitudes of introspection, reflection, emotional character, and concern for the future marked the responses of those who answered.

Keywords: beef, consumption, zoophagy, sarcophagi, market segmentation.

Resumo: Crenças, normas sociais e tabus alimentares influenciam as emoções que sentimos em relação aos alimentos, sendo determinantes das nossas atitudes e comportamentos de consumo. Quanto mais um produto representar valores considerados importantes aos indivíduos, maior a chance de serem escolhidos para o consumo. Este artigo objetivou investigar níveis de zoofagia e sarcofagia para propor um índice como forma de compreender as atitudes dos consumidores em relação à carne bovina. Trezentos e oitenta e cinco pessoas responderam a um questionário estruturado que permitiu avaliar traços de personalidade e as atitudes que podem explicar o consumo de carne bovina, bem como sua rejeição. O modelo analítico escolhido para construção do índice de determinação de atitude é o método conhecido como Análise Fatorial. Para a construção do Índice Geral de Degradação (IGD), primeiramente foi proposta a construção de um índice de determinação de atitude associado ao grau de zoofagia. Os resultados indicam que a extroversão, individualismo, festividade e imediatismo foram os traços que melhor caracterizaram atitudes positivas em relação à carne bovina. Por outro lado, atitudes negativas de introspecção, reflexão, caráter emotivo e preocupação com o futuro marcaram as respostas daqueles que declararam.

Palavras-chave: carne bovina., consumo, zoofagia, sarcofagia, segmentação de mercado.

\section{INTRODUCTION}

The symbolic aspect of food represents one of the factors that most influence the consumption of individuals. Proof of this symbolic weight can be observed in any empirical research, asking a consumer what food means to them. Da Matta (1984) explained that the same food can have numerous meanings and such variation is dependent on how people 
think and judge such food. Through social interaction, the rules related to food and eating vary in time and space, being learned from an early age. Therefore, beliefs, values, and emotions related to any food can say a lot about individuals' eating patterns and consumption behaviors.

Jensen \& Meckling (1994) discusses some approaches to the theoretical model for studying human behavior, including the Economic Model, the Sociological Model, the Psychological Model, and the Political Model. In the context of Brazilian research with consumers, the Psychological Model is the main one and in which motivation is present. This study, based on the psychological model, can complement and expand the understanding of the specificities of the Brazilian meat consumer and open a new research front for researchers in marketing, food, and agribusiness.

Motivation or motive can lead an individual to action (Kotler et al., 2019). Therefore, studies that indicate the motivating variables that guide the behavior or purchase action allow organizations to define targeted and segmented strategies, especially for a product like meat that has been questioned by organized groups like vegans (Deckers, 2013).

For Torres et al. (2006), the attributes of a product can be evaluated differently by consumers, because such evaluations depend on the consumers' personalities, consequently, on their individual and collective values. Thus, the more food, through its symbols, represents values considered important to consumers, the greater the chance of being chosen for consumption. Taking red meat as an example, in Western societies, its consumption is valued, for many consumer groups, for being associated with a status symbol, the strength for work, and the guarantee of satiety Cazes-Valette (2005), Barros et al. (2012), Lucchese-Cheung et al. (2012), Farge \& Moretti (2015).

On the other hand, in the context of contemporary food, there are also movements against the excessive intake of red meat consumption and, even, the justified suppression of animal protein, among others, for ethical, health, and environmental reasons. Disregarding the proportionality between consumers and non-consumers of red meat but considering that the appreciation of the animal's intake, the reduction of consumption, and the practice of abstaining from this act represent strategies of meat consumption. A better understanding of the determinants of such strategies can be clues to explain, for example, the transitions in current food models. For research on consumer behavior, it is important to access how consumers classify proteins (healthy $x$ harmful, lean $x$ fat, ordinary $x$ festive, heavy $x$ light) and decide to consume them (fresh $x$ processed, chilled $x$ frozen, meat in slab $x$ cut, fresh $x$ canned).

In the late 1980s, Noelie Vialles shed light on a complex and obscure system that defines the meat diet in the modern world. According to Vialles (1987), the way individuals choose and prepare animals to be consumed is related to symbols, which determine a double strategy of meat preparation and consumption, zoophagy, and sarcophagy. The first, without any change in shape, value the animal's presentation as it is, and can even be presented whole (for example, a fish or a piglet). The second proposes to mischaracterize the animal, valuing the consumption of its parts without being recognized (steaks, cuts of meat with culinary dishes such as stroganoff and sausages). Denying the death of the animal intended for human consumption and the difficulty in recognizing parts of an animal or the animal itself in one's food are sarcophagic characteristics.

To measure the sensitivity of consumers from different countries in Europe concerning the consumption of red meat, Gautier (2001) validated a scale of zoophagy (acceptance of the individual to recognize an animal as food) and sarcophagy (difficulty and malaise) the individual's ability to recognize an animal as food) through attitudinal and ideological determinants. On this scale, the individual expressed his value system, which was measured by personality indicators and other affective, symbolic, and imaginary indicators of the attitude towards meat. Gautier (2001) zoophagy and sarcophagy scale was also tested by Cazes-Valette (2005) in France. The results were interesting because consumption was not explained only by socioeconomic and demographic variables. The attitude and behavior towards meat explained, for example, the different points of view about the relationship between man and nature, about the ways of thinking and accepting the slaughter of animals 
for consumption, about the frequency of consumption, the ingested volume, and cutting and cooking preferences.

Motivated by the results of personality studies and their influences on human attitudes, this article seeks to propose an index of zoophagy and sarcophagy concerning beef for the Brazilian scenario. A group of consumers from the Midwest region was interviewed using the Gautier scale (2001). One of the reasons for choosing the group is the fact that they live in the region where the research was carried out and their curiosity concerning the registration of Vigitel Brasil (2014) and Dias et al (2015) that attribute the national leadership in the volume of fatty meat ingested to the capital of Mato Grosso do Sul. In addition to access to descriptive information disclosed in food surveys, this article intends to provide explanations about the beef abundant food model. The proposition of the zoophagy and sarcophagy index will make it possible, among other results, to measure the influence of personalities on attitudes related to food choice. Thus, it can be said that the results of this work will contribute to the evolution of research on consumption behaviors, when they admit the action of unconventional determinants on the attitude of individuals, and when they present an analytical model for building indexes.

This study was financed in part by the Federal University of Mato Grosso do Sul and Coordenação de Aperfeiçoamento de Pessoal de Nível Superior - Brasil (CAPES) - Finance Code 001.

\section{MATERIAL AND METHODS}

Personality traits influence people in the way they set different priorities concerning their choices, lifestyle choices, and how they perceive the messages communicated to them. Gautier (2001) stated that similar sociodemographic and economic characteristics of individuals do not determine identical ways of thinking about the same product. The diversity in postmodern consumption behaviors was considered by the author in his studies conducted in several European countries to measure the influence of different personality traits in attitudes related to food choices. To develop a personality scale, the author considered the following characteristics: anxiety, conformity, need for strong sensations, extroversion, suggestibility, sensitivity, flexibility, fantasy, luxury, monetary management, drive, innovation, desire to possess, frustration, collectivity, and hedonism. As a result, factor scales were presented, showing which characteristics of certain personality traits were more explanatory of attitudes towards the product studied. The author verified the relationship between certain characteristics of personality traits and oppositions when they appeared in opposite factor quadrants, revealing that there are different ways of thinking about the consumption of food.

Other research on consumption intention also recognizes that individuals' ways of acting are determined by their value systems, their beliefs, their social rules, and by taboos (Verbeke et al., 2015; Hung et al., 2016). Judgments guide the acceptance of food, and its choice is conditioned by how it best represents a lifestyle, an activist stance, or conduct. In studies conducted in Belgium, Verbeke et al. (2015) proved that the greatest motivations for the purchase and consumption of food products were justified by their adaptations to an individuals' morals.

In the specific case of beef, Wezemael et al. (2010) intending to have access to how individuals from four European countries perceived stimuli related to the product, found that, concerning the search for information (for example, label reading, meat preparation, explanation about types of cut, the guarantee of origin and information about a brand), groups considered to have a lower level of emotional stability (more insecure, suggestible, who always follow what others think, more pessimistic, or even those who always need external stimuli to be alone) showed greater sensitivity to the lack of information. For this group, the lack of information about a product leaves them confused and more insecure, affecting their decision and influencing their attitude. The authors point out that in times of food crisis, such as avian or swine flu, the need for access to information for consumer groups such as that described is even greater.

Personalities are a characteristic that makes an individual unique, causing their intentions to communicate values, to often be reflected in their attitudes (Torres et al., 2006; 
Jones et al., 2015). Regarding the meaning of attitude, Ajzen (2001) presents three underlying dimensions for his analysis: that of knowledge (the cognitive component), that of feeling (affective component), and that of action (the cognitive component). That means an attitude is always based on some belief, judgment, or knowledge about something. In food choice judgments, in general, individuals act concerning what they feel. If positive emotions are felt, the tendency is towards acceptance, otherwise, rejection (Ajzen, 2001). Cognitions or knowledge are also beliefs and associations that people have about something. Affections represent feelings, the state of mind concerning what is observed and judged.

Thus, as already stated in this article, it is argued that decision-making in food consumption suffers multivariate influence, with multiple determinants. Therefore, it must be considered that decisions are also dependent on individuals' ways of thinking about food, their values, the symbols that food has for individuals, their different needs, their concerns about bad choices made, and the meanings that these bad choices will have for themselves and others. The level of consumer involvement with each of these issues varies between individuals and can be better understood through personality studies (Dhont \& Hodson, 2014; De Backer \& Hudders, 2015).

Expression of affection, precaution, and concern for the future represent attitudes that reflect personalities and moral values, influencing choice, and consumption. For the specific case of red meat, these statements could explain, for example, the preference of some consumers for the purchase of certified products, with traceability and information on care for animal welfare in the production of protein. Therefore, considering that the attitude towards beef can be influenced by the way consumers think about animal protein intake (acceptance or rejection in recognizing that the animal is present in their food), the theoretic background of this article to explain the zoophagy and sarcophagy index constructed in this article is justified. Below is further information about the scale used, the sample, and the data processing techniques.

\section{METHODOLOGY}

To carry out this study, we opted for the technique of applying a questionnaire through the survey method. According to Malhotra (2012), the survey method consists of seeking information through questioning the interviewees as to their behaviors, attitudes, perceptions, and motivations, in addition to their demographic characteristics and lifestyle.

The structured questionnaire was composed of seventy-two questions. The independent variables were:

- sixteen questions about the personality traits that make up Gautier's scale (2001).

- three questions about the interviewee's opinion regarding how a man should behave to nature (man must protect nature, dominate nature or control through production techniques) used in the study by Cazes-Valette (2005)

- five questions about the socioeconomic and demographic profile (income, age, gender, education, and marital status).

All independent variables can be viewed in Tables bellow, in the results and discussion section. As dependent variables, questions that could indicate zoophagic and sarcophagic attitudes were adapted from the work of Cazes-Valette (2005), which are: frequency of consumption, consumption occasions, commensality, cooking methods, preference for cooking point, preference for the type of cut; preference for the presence of fat in the meat, place of consumption, confidence in production chain agents, positive opinions on meat consumption, negative opinions on meat consumption, feeling about the meat offered the points of sale - disgust or pleasure in seeing meat hanging, cut types preferred during the week and types chosen for the weekend, preference for white meat and prevalence of beef preference between genders).

The sample size was calculated for data collection. Considering that the research was carried out in the municipality of Campo Grande, according to Hair et al. (2010) using a 95\% confidence interval and standard error of 5\%, to calculate the size of the simple random sample of the population description, at least 385 individuals would have to be interviewed. 
Regarding the adequacy of the study sample, it is worth mentioning that a private company, specialized in market research, was hired for the questionnaire application phase. The random sample was constituted by stratification (considering the proportion referring to education, gender, and income) based on the population indicators of the Campo Grande municipality available at the Brazilian Institute of Geography and Statistics (IBGE, 2012). Finally, it should be added that the respondents are consumers and non-consumers of beef, all over 18 years of age.

As mentioned, Gautier's (2001) zoophagy and sarcophagy scale was tested by CazesValette (2005), in France. The methodological option of this article is justified by the interest in testing the scale in Brazil and proposing an index of zoophagy and sarcophagy for the Brazilian scenario. However, as the field research could only be carried out in a single state in the country, covering individuals from a single municipality does imply there are limitations, and that it is impossible to generalize results and make comparisons using results from the index application in other states and Brazilian municipalities.

\section{Analytical Model}

The analytical model chosen to construct the attitude determination index is the method known as Factor Analysis. This analysis model encompasses a set of statistical techniques, where the main idea is based on being able to describe the variability of a set of $p$ original variables $\mathrm{X}_{1}, \mathrm{X}_{2}, \ldots, \mathrm{X}_{\mathrm{p}}$ with the least number of random variables, also called common factors, and thereby better understand how these variables are related (Hair et al., 2010; Mingoti, 2013).

Authors such as Manly (2008) and Mingoti (2013) point out that the factor analysis has similar objectives to the analysis of main components, both of which are indicated to understand the covariance structure and correlations of the population. Mingoti (2013) states that in the exploratory analysis the researcher seeks to identify the factors related to the original variables (the researcher does not know how precisely determine the number of factors that are part of the model and what they represent).

According to Hair et al. (2010), based on their correlations, the variables are grouped so that each variable in a certain group, or factor, is highly correlated with the other variables. The same author points out the relevance of understanding how much of a variable's variance is shared with other variables within a factor, as opposed to what cannot be shared. Thus, the total variation of any variable can be divided into three parts: (1) the common variance, or commonality, is understood to be the amount of common variation between one variable and all others belonging to that factor; (2) the specific variance, or uniqueness, is the variance that refers only to a single variable; (3) the error variance, or simply an error, is the part of the total variance attributed to measurement errors, the lack of reliability in data collection or even to a random component (Hair et al., 2010; Mingoti, 2013)

The total variance is considered as the sum of commonality, with uniqueness and error. Because they are not explained by correlations with other variables, uniqueness and error can integrate a common " $\varepsilon$ " plot. The total variance of the variables $X_{1}, X_{2}, \ldots, X_{p}$ can be represented in the matrix form by:

$$
X_{p x l}=A_{p x r} F_{r x l}+\varepsilon_{p}
$$

Where:

$X=$ Vector of the original variables.

$\mathrm{F}=$ Vector of common factors (commonality).

$A=$ Matrix (pxr) of factorial loads.

$\varepsilon=$ Vector of specific factors (uniqueness) plus error.

Hair et al. (2010) points out that in real situations, the parameters of the factorial model are unknown and need to be estimated from a random sample of size $\mathrm{n}$. The first factor chosen is intended to maximize the sum of the squares of the related factor loads. The next 
factors will be chosen for the same purpose, to maximize the sum of squares of the factor loads. Thus, there is a way in which factors are chosen.

In this study, the selection of the ideal number of factors was made using the latent root criterion. This criterion determines the selection of factors by the latent root values, always having to be greater than 1 (Hair et al., 2010). After selecting the number of factors, the Varimax orthogonal rotation technique is used, which distributes the factor loads among the selected factors. Such a technique consists of rotating the axes of the factors around the origin "until some other position is reached" (Hair et al., 2010), making the factor loads of the variables significant in only one factor. Therefore, the main objective of the rotation of the factors is to allow an easier interpretation of the empirical result, conserving its statistical properties (Tabachnick et al., 2007).

The procedure called Varimax selects the orthogonal transformation $\mathrm{T}$ that maximizes $\mathrm{V}$, so its formula is described as:

$V=\frac{1}{p} \sum_{j=1}^{m}\left[\sum_{i=1}^{p} \tilde{a}_{i j}^{* 4}-\frac{1}{p}\left(\sum_{i=1}^{p} \tilde{a}_{i j}^{* 2}\right)\right]$,

where $\tilde{a}_{i j}=\frac{\hat{a}_{i j}^{*}}{\hat{b}}$ it is characterized as the square root of commonality. The "pull" of the squares of the loads ${ }^{h_{i}}$ on each factor as much as possible is what corresponds to the maximization of $\mathrm{V}$, hoping to find defined groups of coefficients for each factor column.

For the construction of the General Degradation Index (IGD), it was first proposed to build an attitude determination index associated with the degree of zoophagy, according to Gujarati \& Porter (2006) and using the normalized factor scores $\left(F_{i j}^{*}\right)$. Thus, for the case of the index proposed in this article, there was a transformation in the factor scores of beef consumers, where the lowest value was represented by zero and the highest value represented by one. This normalization is done by the following the algebra expression:

$F_{i j}^{*}=\frac{F_{i j}-F_{j}^{\min }}{F_{j}^{\max }-F_{j}^{\min }},(3)$

where $F_{i j}^{*}$ is the $\mathrm{j}$-th factorial score of the $\mathrm{i}$-th municipality, $F_{j}^{\min }$ is the lowest score observed for the j-th factor, and $F_{j}^{\max }$ is the highest score observed for the j-th factor.

So, the construction of the attitude determination index relates the normalized factor and the characteristic roots in the following form:

$I S_{i}=\sum_{j=1}^{p} \frac{\lambda_{j}}{\sum \lambda_{j}} F_{i j}^{*},(4)$

where is the zoophagy determination index is the $\mathrm{i}$-th individual, the $\lambda_{j}$ is aaj-th characteristic root, $\mathrm{p}$ is the number of factors extracted in the analysis, and $\sum \lambda_{j}$ is the sum of the characteristic roots referring to the extracted factors.

The sarcophagy index was obtained in the same way. It should be added that, according to Gujarati \& Porter (2006), the estimation of the Tobit model parameters is done through the maximum likelihood method, where the known and unknown observations of a censored sample are estimated. According to Greene (2003), the general formulation of the Tobit model is expressed using the efficiency scores as a dependent variable, and the independent variables being the determinants of efficiency. Below you will find the description of the index obtained through the treatment of the data in this research. 


\section{RESULTS AND DISCUSSION}

The measurement of zoophagy (acceptance to recognize the animal as food) and sarcophagy (refusal to recognize the animal as food) indexes through the determining factors allowed to verify how much the independent variables positively or negatively determined the degree of zoophagy and sarcophagy of individuals. Regarding the attitude of accepting the recognition of the animal in the food (zoophagy), the analysis applied allowed ten factors with a characteristic root larger than the unit to be identified, summarizing the information present in the selected variables. When the rotation was performed, it was found that the ten factors selected together explain $56 \%$ of the data variance (Table 1 ).

Table 1. Characteristic root and accumulated variance in percentage

\begin{tabular}{ccc} 
Factor & Characteristic Root & Variance (\%) () Accumulated \\
Factor 1 & 6.86089 & 19.06 \\
Factor 2 & 2.27949 & 25.39 \\
Factor 3 & 2.06906 & 31.14 \\
Factor 4 & 1.59876 & 35.58 \\
Factor 5 & 1.47107 & 39.66 \\
Factor 6 & 1.29416 & 43.26 \\
Factor 7 & 1.26221 & 46.77 \\
Factor 8 & 1.25527 & 50.25 \\
Factor 9 & 1.07259 & 53.23 \\
Factor 10 & 1.00460 & 56.02 \\
\hline
\end{tabular}

Source: Results of the work

The KMO (Kaiser-Meyer-Olkin) analysis, which tests the consistency of the data by identifying its adjustments (comparing simple and partial correlations), was excellent 0.8467 (Melo \& Parré, 2007).

Table 2 shows the factorial loads (correlation between the original variable and the factor, the higher the load the greater the correlation) and the specificities for the factor (meaning the error, or the portion of the variance not explained by a factor and, therefore, the lower the specificity, the greater the relevance of the variable in the factor model). Considering the objective of this work, the factor loads considered were greater than 0.4.

Factor 1 is strongly related to the variables that indicate hedonic behaviors about beef and, therefore, when they think about good food, they think about meat (X28). The pleasure and motivation in consuming meat are characterized by a high frequency of consumption during the week, with a pot or cooked meat, and on weekends with barbecue (X21, X22, and $\mathrm{X} 23)$. Cattle are considered as a source of protein for man, that is, the animal is thought of as food (X35). The pleasure was also expressed in seeing and choosing the meat pieces hanging in the butcher shop (X36). Information that warns about the problems of consuming in excess is disregarded (X45) because they state that eating meat is good for health (X20). The determining variables are linked to consumption motivations explained by symbols that represent the pleasure of consuming beef.

Factor 2 is strongly related to indicators that represent the non-consideration of the risk of consuming beef cattle (X60). The most determinant variables indicate a preference for the rump cut for barbecues (X32), the choice to consume animal protein at the dinner meal (X58), and the lack of concern about supply in the markets because even in times of reduced supply they say they will continue to consume (X59). 
Table 2. Factorial loads and their specificities for all issues

\begin{tabular}{|c|c|c|}
\hline Factors & $\begin{array}{l}\text { Factorial } \\
\text { Weights }\end{array}$ & Specificities \\
\hline \multicolumn{3}{|l|}{ Factor 1 - Identity with meat } \\
\hline X20 - Meat is good & 0.6797 & 0.3967 \\
\hline X21 - Daily beef consumption & 0.7648 & 0.2794 \\
\hline X22 - Weekdays, pot roast & 0.6093 & 0.4813 \\
\hline X23 - Weekend, barbecue & 0.5562 & 0.5650 \\
\hline $\mathrm{X} 28$ - Good food is beef & 0.4292 & 0.5314 \\
\hline X35-Animal is food for humans & 0.4118 & 0.5513 \\
\hline X36 - I like to see meats hanging in the butcher shop & 0.4455 & 0.4052 \\
\hline $\begin{array}{l}\text { X45 - Even though I know it can be bad for my health, I like it and keep eating } \\
\text { meat }\end{array}$ & 0.4360 & 0.4496 \\
\hline \multicolumn{3}{|c|}{ Factor 2 - Occasion of meat consumption } \\
\hline X32 - Good barbecue is made with rump & 0.5667 & 0.4179 \\
\hline X58 - At dinner, I prefer beef & 0.6405 & 0.4300 \\
\hline X59 - Even if there is no market, I will not decrease consumption & 0.6886 & 0.3264 \\
\hline X60 - I don't think about the risk of consuming excess meat & 0.4740 & 0.4513 \\
\hline \multicolumn{3}{|c|}{ Factor 3 - Meat knowledge and information } \\
\hline X47 - Knowledgeable of first and second cuts & 0.5402 & 0.4411 \\
\hline $\mathrm{X} 48$ - Origin certification is synonymous with quality & 0.7067 & 0.4033 \\
\hline X55 - I know certified meat and I overpay for it & 0.6492 & 0.4607 \\
\hline X61 - Butcher shop that sells certified meat is safe and has quality & 0.4631 & 0.5360 \\
\hline \multicolumn{3}{|c|}{ Factor 4 - Benefits of meat consumption } \\
\hline X41 - Eating meat makes me feel stronger, with more energy & 0.6081 & 0.3243 \\
\hline X42 - To have the energy for work, meat must be eaten & 0.6155 & 0.3620 \\
\hline X57 - I eat meat and incorporate the strength of the animal & 0.7551 & 0.3186 \\
\hline \multicolumn{3}{|c|}{ Factor 5 - Relevant factors in the purchase decision } \\
\hline $\begin{array}{l}\text { X54 - Concern about high cholesterol would be a reason to stop consuming } \\
\text { meat }\end{array}$ & 0.5595 & 0.4832 \\
\hline X56 - Fresh meat, the redder, the fresher it is & 0.5786 & 0.5977 \\
\hline X62 - It's where you buy the meat that matters & 0.5920 & 0.5178 \\
\hline \multicolumn{3}{|l|}{ Factor 6 - Meat flavor attributes } \\
\hline X25-Good meat is meat with fat & 0.7259 & 0.3940 \\
\hline X38 - I like medium-rare meat & 0.5618 & 0.3863 \\
\hline X51 - Streaky fat is synonymous with more flavor and softness & 0.5688 & 0.5007 \\
\hline \multicolumn{3}{|c|}{ Factor 7 - Relating with the where the meat is purchased } \\
\hline X53 - Trust, I have it in the butcher & 0.6719 & 0.4842 \\
\hline X63 - Buy where it's cheaper & 0.4625 & 0.4175 \\
\hline X65 - I trust where I buy my meat & 0.7201 & 0.4273 \\
\hline \multicolumn{3}{|c|}{ Factor 8 - Beliefs about meat consumption } \\
\hline X30 - Steak must be made with prime beef & 0.4419 & 0.3594 \\
\hline X39- Bleeding meat is more accepted by men & 0.7300 & 0.4187 \\
\hline X40 - Woman can stay longer without eating meat & 0.7115 & 0.3628 \\
\hline \multicolumn{3}{|c|}{ Factor 9 - Perception of thetypes of meat } \\
\hline X31 - Pot meat with choice meat & 0.6700 & 0.4427 \\
\hline X33 - Daily meat is ground meat & 0.6677 & 0.4133 \\
\hline \multicolumn{3}{|c|}{ Factor 10 - Perception about meat quality and safety } \\
\hline X64 - Beef is safe and has quality because inspection exists and is strong & 0.6591 & 0.4428 \\
\hline
\end{tabular}

Source: Study results 
Factor 3 is related to the symbols that represent the quality of beef. The variables of this factor indicate that the consumer is familiar with types of cuts (X47), attaches importance to the food certification (X55), and accepts that retailers place a premium price on meat that has origin certification and that guarantees that it is male (X48). In addition to gender and traceability indicators, the quality was related to food safety for consumption, which can be guaranteed by the point of sale when it offers certified meat (X61).

In factor 4, the symbolic values related to the incorporation of the animal's strength through the consumption of its meat predominate, being able to guarantee energy for work and physical strength (X41, X42, X57).

Factor 5 is related to other types of concerns. Health concerns would be a motivation to decrease consumption (X54). Variables that represent the color of the meat and aspects of the place of purchase are positive attitudinal determinants of consumption (X56 and X62).

Factor 6 is positively related to variables that represent the local culture, such as the preference for meat with fat (X25), rare (X38), and the opinion that streaky fat is synonymous with tenderness and flavor (X51).

Factors 7 and 8 predominate variables that indicate, respectively, confidence and value judgment regarding consumption. Confidence in buying is associated with the butcher and the place of purchase (X53 and X65). Exceedingly rare meats are more preferred by men than women (39), who can stay longer without consuming protein than men (X40).

The last factors 9 and 10 are related to the mode of consumption (as the variable X31 pot meat is made with choice cuts and the variable X33 with ground meat chosen for everyday use) and the confidence in the inspection that, for the consumer, makes it legitimate to buy meat found at points of sale that have the lowest prices (X63 and X64).

In general, consumption indicators that represent positive symbols related to beef contributed to the formation of all factors. Such symbols were justified by determinants such as pleasure, choice of preparation methods (separation for ordinary days and the festive day, Sunday is barbecue), incorporation of the animal's strength and energy, and quality signs. It is known that the interviewees represent a municipality that is a strong consumer of beef cattle. But it should be remembered that for an exploratory study like this, the research's interest is to understand how much individual and collective personalities and values can explain this food model.

According to the steps described in the analytical model, through factor analysis, it was possible to understand how the dependent variables were related and what their contributions to the formation of factors (Table 2, results of factor analysis). Figure 1 shows the most significant variables in factor loads and with the lowest specificities found, that is, the greatest relevance for the factor model. Paying attention to the variables that showed the greatest correlations, positions that are aligned not only with food hedonism are revealed, but also behaviors that indicate little concern for the future. Some signs of quality, used in the structuring of beliefs, appear when individuals attribute to the certification, the point of sale, and the figure of the butcher the condition of accreditors of the attributes of the beef's quality.

Finally, it is worth mentioning the difference found in the relationship that the genders have regarding the consumption of beef. Among all foods, red meat is perhaps the one that carries the most symbolic weight. A symbol of strength and energy is preferred rare by men while women reject the consumption of blood and manage to refrain from incorporating strength and energy. As the other variables did not allow us to explain the results on the difference in consumption between genders, a limitation of the research is recognized here. 


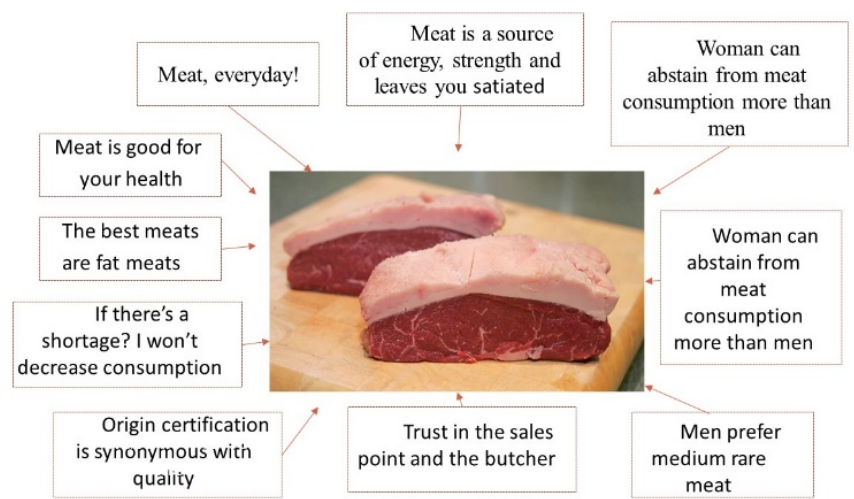

Figure 1 - Strength of dependent variables for the formation of factors

Source - Study results

Following the steps described in the analytical model, for the proposition of the zoophagy and sarcophagy index, measurements must be continued that will indicate the most characteristic attitudes of the facility in recognizing the animal as food and, on the other hand, of the difficulty in thinking about the animal as one's food. An analysis based on Churchill Junior (1979) was carried out where 6 factors were generated, explaining almost 74\% of the variance (see Table 3).

Table 3. Factor weights and their specificities for issues related to zoophagy

\begin{tabular}{|c|c|}
\hline Factors & $\begin{array}{l}\text { Factorial } \\
\text { Weights }\end{array}$ \\
\hline \multicolumn{2}{|l|}{ Factor 1 - Refusal of beef } \\
\hline I eat beef, but I feel better eating white meats & 0.8925 \\
\hline I eat beef, but I don't like it very much & 0.8723 \\
\hline \multicolumn{2}{|l|}{ Factor 2 - Healthy meat consumption } \\
\hline If I must choose a piece of meat, I prefer the leanest, healthiest & 0.8635 \\
\hline I like meat with fat & $-0.8488^{*}$ \\
\hline \multicolumn{2}{|l|}{ Factor 3 - Gender and beef } \\
\hline I think a woman can go longer than a man without eating beef & 0.8344 \\
\hline I think bleeding meat is more of a man's food than a woman's & 0.8329 \\
\hline \multicolumn{2}{|l|}{ Factor 4 - Beef and its symbolism } \\
\hline When I eat meat, I feel stronger, I almost incorporate the strength of the animal & 0.8584 \\
\hline I always heard that if you want to have the energy for work you must eat meat & 0.7677 \\
\hline \multicolumn{2}{|l|}{ Factor 5 - Certification in the purchase of beef } \\
\hline I know what certified meat is and would pay a little more for it & 0.8196 \\
\hline A butcher shop that sells certified meat has more quality and safety & 0.8167 \\
\hline \multicolumn{2}{|l|}{ Factor 6 - Rejecting the idea of thinking of beef as food } \\
\hline I think the animal is our food and I don't wonder how they live & 0.7983 \\
\hline I disgust those pieces of meat hanging in the butcher shop & $-0.7926 *$ \\
\hline
\end{tabular}

*Questions could be modified to have a positive factor weight

Source: Study results

After the presentation of the factorial weights, attention should be paid to the results obtained with the factor scores (value of the factor for each independent variable analyzed in the study). Thus, for the construction of the index, the calculation of factor scores was 
observed, and the original scores were considered as variables with a mean zero, and standard deviation equal to one. It is understood, therefore, that scores with a value close to zero will indicate an average zoophagic attitude determination (acceptance to recognize the animal as food), while negatives will indicate little influence on such attitude. However, the closer the score is to 1 , the more the independent variable will strongly determine the zoophagic attitude of the individuals in the study. With the application of the Tobit model, which identified the most determinant factors of zoophagy, it was verified whether the independent variables included in the model (personality variables, relationship with nature in addition to those indicative of socioeconomic and demographic situation) influenced the dependent variables (consumption attitudes). Finally, it is worth explaining that the values presented in Table 4 are derived from the calculation of Tobit's marginal effect, which measured the impact of each variable on the probability of the decision-making unit's efficiency (Santos et al., 2009).

Table 4. Zoophagy index

\begin{tabular}{|c|c|c|c|}
\hline Independent variable & Coefficient & $\mathbf{z}$ & $\mathbf{P}>|\mathbf{z}|$ \\
\hline $\mathrm{X} 1$ - I get involved in the problems of others & .0108115 & 2.70 & 0.007 \\
\hline X2 - I solve everything by myself and think of myself when taking actions & .0046305 & 1.03 & 0.305 \\
\hline X3 - I don't like to upset anyone & .0056855 & 1.13 & 0.259 \\
\hline X4 - I'm unlucky & .010893 & 2.22 & 0.026 \\
\hline X5 - I always make new friends & .0154887 & 3.28 & 0.001 \\
\hline X6 - I daydream, I imagine things & .0052135 & 1.11 & 0.268 \\
\hline X7 - I don't deal well with the unexpected & .0077419 & 1.62 & 0.106 \\
\hline X8 - I need to be with friends, I need festive moments & .0060029 & 1.27 & 0.204 \\
\hline X9 - I impulse buy & .0030918 & 0.64 & 0.521 \\
\hline X10 - I like to start from scratch & .0056297 & 1.13 & 0.260 \\
\hline X11 - I like luxury, expensive things & .0057858 & 1.09 & 0.274 \\
\hline X12 - I value the money I have & .00392 & 0.79 & 0.431 \\
\hline X13 - I don't lend anything & .0046212 & 1.00 & 0.316 \\
\hline X14 - I am very emotional & -.0035204 & -0.79 & 0.427 \\
\hline X15 - I am easily influenced & .0007828 & 0.15 & 0.877 \\
\hline X16 - I like strong emotions & -.0039157 & -0.91 & 0.365 \\
\hline X17 - We must manage nature with production techniques & .0095074 & 2.04 & 0.041 \\
\hline X18-Man should simply protect nature & .0096204 & 1.44 & 0.149 \\
\hline $\mathrm{X} 19$ - Man must dominate nature because he is superior & 0.136 .333 & 2.56 & 0.010 \\
\hline X67-Gender & .043884 & 2.48 & 0.013 \\
\hline X68 - Education & -.033858 & -3.38 & 0.001 \\
\hline X69 - Household income & .0167119 & 2.23 & 0.026 \\
\hline X70 - Marital status & -.0054419 & -0.80 & 0.424 \\
\hline X71 - Age & .0064478 & 1.00 & 0.315 \\
\hline
\end{tabular}

Source: Study results 
Table 4 shows how much each independent variable is a determinant of the efficiency of the dependent variables in explaining food zoophagy behaviors (interviewed group ease to accept and recognize that animals are food for humans). This analysis was interested in the scores of strong and medium zoophagy determination. Scores with weak determination will only be analyzed if their contribution is interesting to understand the zoophagic attitude.

The personalities that influenced the most zoophagic attitudes were more determined by two qualities that, according to Wezemael et al. (2010), reveal a lower level of emotional stability, being the variables X1 - they have insomnia and are easily involved in other people's problems, in addition to considering themselves to be unlucky people (X4). However, in terms of the strength of determining the independent variables, X5 - I always make new friends, as compensation and need for well-being, stands out.

It is interesting to note that the thinking patterns defined by the index that measured the highest levels of zoophagy also revealed the determination of opinions such as X19 - man must dominate nature, and X17 - man must manage and control nature. This result corroborates what was found by Cazes-Valette (2005). Individuals with more zoophagic attitudes judge nature and animals as a means of producing what they need and a product for their consumption.

About the explanation weight of the socio-demographic and economic variables, which are less expressive in determining the efficiency of the explanation of the index, but still, determinant, gender (X67), and income (X69) must be considered to explain zoophagic attitudes. Men, more than women, accept animals better as food and feel better about recognizing their parts at meals, as well as finding them whole at meals. Zoophagy increase is best represented by average income levels, indicating that increased income increases zoophageal attitudes. Although with a strongly negative score, it was considered interesting to mention the influence of the marginal effect of variable X68 (education), which indicates that the zoophagy index is more characteristic of lower levels of education. The higher the level of education, it appears that attitudes of acceptance to recognize the animal as food decrease.

Taking an index as a reference factor, explaining a situation, the zoophagy index presented allows for some analysis. Considering the efficiency scores (six factors presented in Table 3 that indicated the most representative zoophagic attitudes for the individuals studied) and the determinants of that efficiency (independent variables that best explained the attitudes), it is seen that the statements of the individuals concerning beef, they are supported by a set of values and rules that explain a way of thinking about the animal and reveal interesting information about trends in consumer behavior.

The animal is in the collective consciousness of those individuals as an important source of daily food. Familiarity and frequency, justified by the contribution of energy, strength, and satiety, allow statements of lesser merit when it is overlooked concerning other sources of animal protein (valorization of white meat), an action understood as a symbol of distinction. It is noted, however, that the zoophagic attitude values red meat as a contribution to health, but justifies this value no longer because of the fat or hedonism in recognizing it at the point of sale through large exposed pieces, but by its signs of quality (certification, safety, and health).

Determining this degree of zoophagy found (Figure 2), there are mainly patterns of grief characterized by a high degree of affability (extroversion, ease in making new friends), being sensitive to the problems of others. Certain of the animal's condition as food, man must master nature and manage it through production techniques. Regarding the importance of determining these independent variables, attention is drawn to education and gender. The index explains that the described zoophagic attitudes are better represented in the opinion of men and these attitudes are also more present with progressive increases in declared incomes but regressive in levels of education. As already mentioned, the independent variables of personality and opinion about the domination of nature by man strongly determined the zoophagic attitude to the detriment of the sociodemographic and economic ones. 


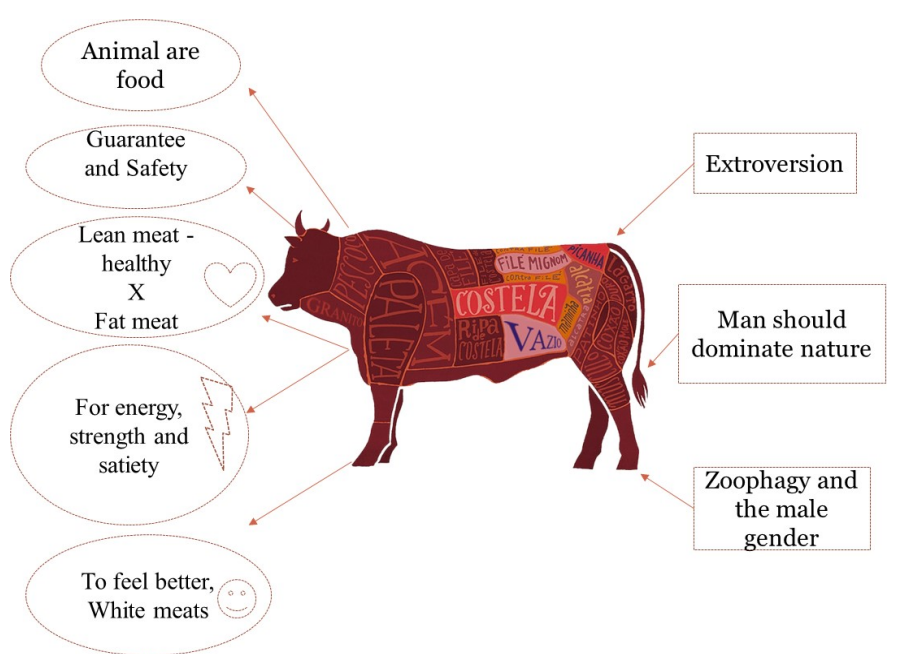

Figure 2 - Determination of the zoophagic attitude Source - Study results

The index that classifies individuals' attitudes according to the most sarcophagic statements of consumption is presented below. Four factors with a characteristic root larger than the unit summarize the information present in the thirteen selected variables. When the rotation was performed, it was found that the four factors selected together account for $61.56 \%$ of the data variance.

Table 5 shows the factorial weights (correlation between the original variable and the factor, the greater the load, the greater the correlation) and the specificities for the factor (meaning the error, or the portion of the variance not explained by a factor and by this, the lower the specificity, the greater the relevance of the variable in the factorial model). Considering the objective of this work, which is to carry out the analyzes intended, the factor weights considered were greater than 0.4 .

Table 5. Factor weights and their specificities for issues related to sarcophagy

\begin{tabular}{|c|c|c|}
\hline Factors & $\begin{array}{l}\text { Factorial } \\
\text { Weights }\end{array}$ & Specificities \\
\hline \multicolumn{3}{|c|}{ Factor 1 - Sarcophagic motivations } \\
\hline X26 - I eat meat, but I don't like it & 0.7752 & 0.2852 \\
\hline X27- I feel better eating white meats & 0.7035 & 0.3818 \\
\hline $\begin{array}{c}\text { X34 - I feel sorry when I think of the cows being slaughtered for } \\
\text { consumption }\end{array}$ & 0.6989 & 0.4627 \\
\hline X50 - Livestock raising is a problem for the environment & 0.6535 & 0.4909 \\
\hline $\begin{array}{l}\text { X46 - Reduce consumption of red meat, read labels, pay attention to } \\
\text { tips from nutritionists }\end{array}$ & 0.5951 & 0.4347 \\
\hline X37 - I feel disgusted when I see meat hanging in the butcher shop & 0.5752 & 0.5665 \\
\hline X29 - I don't eat beef & 0.5687 & 0.4678 \\
\hline X44 - It is more elegant to serve white meat when serving visits & 0.5484 & 0.4779 \\
\hline \multicolumn{3}{|c|}{ Factor 2 - Refusal and rejection of what is marketed } \\
\hline X66 - Meat sold in supermarkets is meat from old animals & 0.4470 & 0.1335 \\
\hline \multicolumn{3}{|c|}{ Factor 3 - Lack of interest in the beef theme } \\
\hline X49 - I don't know anything about beef quality & 0.6873 & 0.4411 \\
\hline X66 - Meat sold in supermarkets is meat from old animals & 0.5579 & 0.1335 \\
\hline \multicolumn{3}{|c|}{ Factor 4 - Refusal and preference for white meat } \\
\hline X66 - Meat sold in supermarkets is meat from old animals & 0.5928 & 0.1335 \\
\hline X44 - It is more elegant to serve white meat when serving visits & 0.4201 & 0.4779 \\
\hline
\end{tabular}

Source: Study results 
Factor 1 is what is strongly related to the most determinant variables of sarcophagic motivations, those that indicate rejection behavior recognition of the animal as food (X26 - I eat beef, but I don't like it, X27 - I like beef, but I feel better eating white meats and X29 - I don't eat beef). In addition to rejection, other characteristic variables of sarcophagic behaviors indicate feelings of pity (X34 - I feel sorry when I think of the cows being slaughtered) and disgust (X37 - I disgust the pieces of meat hanging from the butcher shop). Factor 1 was also related to manifestations that justify positions against eating animal protein (X50 - there are a lot of campaigns saying that cattle breeding is a problem for the environment, X46 - I am more attentive, I like to follow information from nutritionists, I always read the food labels and already reduced the consumption of beef and X44 - I think it is more elegant to serve white meat when serving visits).

Factor 2 was related to variable X66 (beef sold at supermarket butchers is meat from old animals), which indicates refusal and rejection of what is sold.

Factor 3 , in addition to the variable X66 (beef sold by supermarket butchers is meat from old animals), was also related to the lack of interest in beef (X49 - I don't know much about the quality of beef).

Finally, factor 4, representing sarcophagy as an attitude related to beef, was strongly related to two variables, X66 (beef sold in supermarket butchers is meat from old animals) and X44 (I think it is more elegant to serve white meat when serving visits). The refusal and contempt are accompanied by the justification for the preference for white meat.

The presentation of the factor weights is followed by the results of the factor scores (value of the factor for each independent variable analyzed in the study). For the construction of the sarcophagy index, the calculation of the factor scores was observed the fact that the original scores are variables with mean zero and standard deviation equal to one was considered. Scores with a value close to zero will indicate an average determination of sarcophagic attitude, while the negative ones will indicate little influence on such attitude. However, the closer the score is to 1 , the more the independent variable will strongly determine the sarcophagic attitude of the individuals in the study. With the application of Tobit's model, which identified the most determinant factors of sarcophagy, it was verified whether the independent variables (personality variables, relationship with nature in addition to those indicative of socioeconomic and demographic situation) influenced the dependent variables (consumption attitudes). Finally, it is worth explaining that the values presented in Table 5 are derived from the calculation of Tobit's marginal effect, which measured the impact of each variable on the probability of the decision-making unit's efficiency (Santos et al., 2009).

Table 6 shows how much each variable interfered in the sarcophagy index, the difficulty of the interviewed group in accepting and recognizing the animal in the food that will be consumed. It focused on the strong and medium sarcophagy determination scores. Scores with weak determination will only be commented on if they indicate important oppositions to the understanding of the sarcophagic attitude.

The most sarcastic attitudes are a sum of personality traits that reveal feelings, emotion (X14 - I am very emotional), and suggestible behavior (X15 - I am easily influenced). Also, feelings of concern for nature also determine a sarcophagic characteristic, (X18 - man must protect nature). In the work of Cazes-Valette (2005) the most sarcophagic consumption behaviors were justified by positions and food choices that minimize internal suffering, generating positive emotions for individuals. Thus, the choices that organize this type of behavior were marked by actions seeking to protect nature and the option of consuming food that causes little environmental impact, in addition to defending the non-consumption of animals.

Regarding the sociodemographic and economic variables, it is interesting to note that the variables with a strong determination of sarcophagic attitudes were X71 (age, indicating that the sarcophagic attitude increases with age), in addition to X68 (which indicates that such attitudes are more present among individuals with higher levels of education). The same results were found in the works of Cazes-Valette (2005) and Verbeke et al. (2015) when they affirm that motivations in favor of the environment and protection of animals are more present among individuals with a higher level of education and access to information. Furthermore, it is worth emphasizing an observation with a strongly negative score for the attitude of sarcophagy (gender). Women refuse to consider the animal as food more than men. 
Table 6. Sarcophagy index

\begin{tabular}{|c|c|c|c|}
\hline Independent variable & Coefficient & $\mathbf{z}$ & $P>|z|$ \\
\hline $\mathrm{X} 1$ - I get involved in the problems of others & -.0045011 & -1.07 & 0.287 \\
\hline X2 - I solve everything by myself and think of & .0062646 & 1.31 & 0.189 \\
\hline X3 - I don't like to upset anyone & .0062682 & 1.18 & 0.239 \\
\hline X4 - I'm unlucky & .0072835 & 1.41 & 0.160 \\
\hline X5 - I always make new friends & -.0055833 & -1.12 & 0.262 \\
\hline X6 - I daydream, I imagine things & -.0074509 & -1.50 & 0.134 \\
\hline X7 - I don't deal well with the unexpected & .0031094 & 0.61 & 0.539 \\
\hline X8 - I need to be with friends, I need festive & -.0031833 & -0.64 & 0.524 \\
\hline X9 - I impulse buy & .0036252 & 0.71 & 0.476 \\
\hline X10 - I like to start from scratch & .0045023 & 0.85 & 0.393 \\
\hline X11 - I like luxury, expensive things & .0070657 & 1.26 & 0.206 \\
\hline $\mathrm{X} 12$ - I value the money I have & .0065314 & 1.24 & 0.214 \\
\hline X13 - I don't lend anything & .000242 & 0.05 & 0.960 \\
\hline X14 - I am very emotional & .0099801 & 2.13 & 0.033 \\
\hline X15 - I am easily influenced & .012991 & 2.43 & 0.015 \\
\hline X16 - I like strong emotions & -.0001261 & -0.03 & 0.978 \\
\hline X17 - We must manage nature with & -.0091579 & -1.86 & 0.063 \\
\hline X18 - Man should simply protect nature & .0194668 & 2.76 & 0.006 \\
\hline X19 - Man must dominate nature because & .0100846 & -1.79 & 0.073 \\
\hline X67 - Gender & -.0872304 & -4.66 & 0.000 \\
\hline X68 - Education & .0163532 & 1.55 & 0.122 \\
\hline X69 - Household income & -.0180005 & -2.28 & 0.023 \\
\hline X70 - Marital status & -.0196314 & -2.73 & 0.006 \\
\hline X71 - Age & -.0196314 & 2.18 & 0.029 \\
\hline
\end{tabular}

Source: Results of the work

The index explains that the sarcophagic attitudes declared by the interviewed consumers are supported by a set of values and rules, placing beef as a blatant marker of the domination of men over animals, which is strongly denied and determined by the independent variables "I am very emotional" and "men should simply protect nature", in addition to this type of attitude being much more influenced by the female gender (Figure 3).

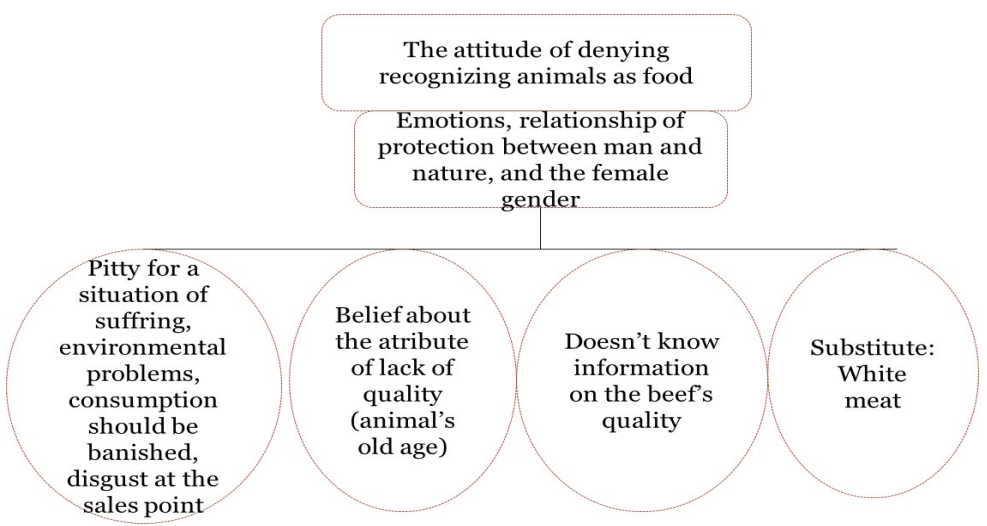

Figure 3 - Determination of the sarcophageal attitude Source - Study results 


\section{FINAL CONSIDERATIONS}

The proposition of the beef acceptance index was useful to think about the attitudes of individuals classified in household surveys as strong consumers of animal protein in Brazil. An incredibly detailed analytical model was proposed, not only so that it could be replicated in other Brazilian states, but for determining other indexes that answer questions from applied research in other productive sectors. It was verified how the variables relate within the factors and among them, as well as to understand what they represent and, later, the determination of the independent variables on the attitudes of zoophagy and sarcophagy was measured.

The results are interesting when they point out statements of strong beef consumers that indicate a desire to reduce their consumption or replace it with white meat, or leaner cuts, for health reasons. Also, food safety and certifications appear as signs of quality, which can be a tip for sector's agents to seek innovation in proposing quality seals and brands for the sector. On the other hand, more sarcophagic attitudes are described by feelings of pity, concern about the environmental problems that arise in the meat chain, as well as distrust concerning the quality of the protein sold in retail.

Such attitudes were determined by feelings of emotion and the belief that man should protect nature. In general, ordinary beef consumers have many doubts about the production system of animals intended for human consumption, and it may be an opportunity for agents in the sector to invest in communication campaigns. The way food is perceived depends on the food culture of individuals that, in turn, guide their attitudes and behaviors. An index of zoophagy and sarcophagy was proposed in this work, intending to measure the intensity of these attitudes among a group of consumers in the Brazilian region that declare itself as the largest consumer of fat meat in the country.

In light of theories that indicate that beliefs, social rules, emotions, and personalities are as the determinant of consumption as economic variables, this work found that the most zoophagic attitudes were determined by personality traits that reveal patterns of behavior that, in turn, indicate dissatisfaction and a need for always wanting more, in addition to extroversion and the desire to always be in a group and party.

The taste, the fat of the meat, the high frequency of consumption, the preference to see the meat hanging, and the fact that they think of animals as a food source for humans characterize zoophagic attitudes. The most emotional individuals, the smallest part of the interviewed group, sarcophagics, revealed negative emotions when talking about beef. They are consumers concerned with their choices because it has an impact for themselves and others.

These reflections are original for marketing and consumer behavior studies, proving that the culture and symbolism of food play an important role in the way of acting and thinking of individuals. Thus, the agents of public and private power are interested in knowing that the taste for beef represents a strong cultural significance and that changes in consumption patterns represent fighting against feelings, emotions, and personal history.

\section{REFERENCES}

Ajzen, I. (2001). Nature and operation of attitudes. Annual Review of Psychology, 52(1), 27-58.

Barros, G. S. D., Meneses, J. N. C., \& Silva, J. A. D. (2012). Representações sociais do consumo de carne em Belo Horizonte. Physis (Rio de Janeiro, Brazil), 22, 365-383.

Cazes-Valette, G. (2005). Genres et viandes: vers un troisième sexe. In Sociologie et anthropologie de l'alimentation.

Churchill Junior, G. A. (1979). A paradigm for developing better measures of marketing constructs. JMR, Journal of Marketing Research, 16(1), 64-73.

Da Matta, R. (1984). O que faz o brasil, Brasil? Rio de Janeiro: Rocco.

De Backer, C. J. S., \& Hudders, L. (2015). Meat morals: relationship between meat consumption consumer attitudes towards human and animal welfare and moral behavior. Meat Science, 99, 68-74.

Deckers J. (2013). In defence of the vegan project. Journal of Bioethical Inquiry, 10(2), 187-195.

Dhont, K., \& Hodson, G. (2014). Why do right-wing adherents engage in more animal exploitation and meat consumption? Personality and Individual Differences, 64, 12-17. 
Dias, L. D.; Isernhagen, L., Brumatti, R. C., Faria, F. J. C., Franco, G. L., Kiefer, C., \& Ítavo, C. C. B. F. (2015). Estudo sobre o padrão de consumo da carne bovina na cidade de Campo Grande, MS, Brasil. Boletim de Indústria Animal, 72(2), 148-154.

Farge, S., \& Moretti, S. (2015). L'Imaginaire culinaire en allemand, espagnol et français: le rapport à la viande. ESSACHESS-Journal for Communication studies, 8(2), 13-25.

Gautier, J.-M. (2001). Psychologie du consommateur et comportement d'achat: mise en place et validation d'une échelle de personnalité. França: Groupe HEC.

Greene, W. H. (2003). Econometric analysis. New Jersey: Pearson Education India.

Gujarati, D., \& Porter, D. C. (2006). Econometria Básica. Rio de Janeiro: Campus e Elsevier.

Hair, J. F., Anderson, R. E., Babin, B. J., \& Black, W. C. (2010). Multivariate data analysis: A global perspective (Vol. 7). London: Pearson Upper Saddle River.

Hung, Y., De Kok, T. M., \& Verbeke, W. (2016). Consumer attitude and purchase intention towards processed meat products with natural compounds and a reduced level of nitrite. Meat Science, 121, 119-126.

Instituto Brasileiro de Geografia e Estatística - IBGE. (2012). POF - Pesquisa de Orçamentos Familiares. Retrieved in 2018 February 10, from

https://ww2.ibge.gov.br/home/estatistica/pesquisas/pesquisa_resultados.php?id_pesquisa=25

Jensen, M. C., \& Meckling, W. H. (1994). The nature of man. Journal of Applied Corporate Finance, 7(2), 4-19.

Jones, M. A., Reynolds, K. E., Arnold, M. J., Gabler, C. B., Gillison, S. T., \& Landers, V. M. (2015). Exploring consumers' attitude towards relationship marketing. Journal of Services Marketing, 29(3), 188-199.

Kotler, P., Keller, K. L., Brady, M., Goodman, M., Hansen, T. (2019). Marketing management. London: Pearson UK.

Lucchese-Cheung, T., Batalha, M. O., \& Lambert, J. L. (2012). Comportamentos do consumidor de alimentos: tipologia e representação da comida. Agroalimentaria, 18(35)

Malhotra, N. K. (2012). Pesquisa de marketing: uma orientação aplicada. Porto Alegre: Bookman Editora.

Manly, B. F. (2008). Statistics for environmental science and management. Boca Raton: Crc Press.

Melo, C. O. D., \& Parré, J. L. (2007). Índice de desenvolvimento rural dos municípios paranaenses: determinantes e hierarquização. Revista de Economia e Sociologia Rural, 45(2), 329-365.

Mingoti, S. A. (2013). Análise de dados através de métodos de estatística multivariada: uma abordagem aplicada. Belo Horizonte: Editora UFMG.

Santos, V. F. D., Vieira, W. D. C., Rufino, J. L. D. S., \& Lima, J. R. F. D. (2009). Análise da eficiência técnica de talhões de café irrigados e não-irrigados em Minas Gerais: 2004-2006. Revista de Economia e Sociologia Rural, 47(3), 677-698.

Tabachnick, B. G., Fidell, L. S., \& Ullman, J. B. (2007). Using multivariate statistics (Vol. 5). Boston, MA: Pearson.

Torres, C. V., Allen, M. W., Pérez-Nebra, A. R. (2006). Consumo no Brasil: um teste etic da relação entre valores humanos, significado do produto e preferência de consumo em culturas coletivas. Revista Psicologia: Organizações e Trabalho, 6(1), 79-105.

Verbeke, W., Marcu, A., Rutsaert, P., Gaspar, R., Seibt, B., Fletcher, D., \& Barnett, J. (2015). 'Would you eat cultured meat?': Consumers' reactions and attitude formation in Belgium, Portugal and the United Kingdom. Meat Science, 102, 49-58.

Vialles, N. (1987). Le sang et la chair (coll. Ethnologie de France). Paris: Ed. de la maison des sciences de l'homme.

Vigitel Brasil (2014). Vigilância de fatores de risco e proteção para doenças crônicas por inquérito telefônico. Retrieved in 2018, December 21, from http://portalsaude.saude.gov.br/images/pdf/2015/abril/15/PPTVigitel-2014-.pdf.

Wezemael, L., Verbeke, W., Kügler, J. O., Barcellos, M. D., \& Grunert, K. G. (2010). European consumers and beef safety: Perceptions, expectations and uncertainty reduction strategies. Food Control, 21(6), 835-844. 